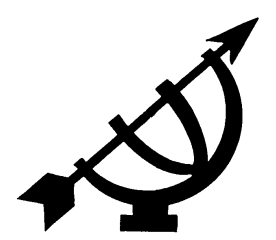

\title{
The spiritual and religious dimension of education and bringing-up ${ }^{1}$
}

\author{
M. Valenkamp \\ Faculty of Education \\ University of Inholland \\ AMSTERDAM \\ E-mail: martin@valenkamp.com
}

\begin{abstract}
The spiritual and religious dimension of education and bringing-up

In this article I will discuss the differences between the concepts "spirituality", "religion" and "faith" and indicate the intertwinement of these dimensions of man's mental life with bringing-up and education. Definitions of these concepts will not be given. Rather, their characteristics will be brought to the fore. The purpose of this article is to look for the essential relation of spirituality to the education and bringing-up of children.

A so-called "religious matrix" will be worked out in which the core questions of spirituality and religion are to be expressed. By means of this matrix, a notion of the relation between spirituality, bringing-up and education will be formulated.

\section{Samenvatting}

De spirituele en religieuze dimensie van onderwijs en opvoeding

In deze artikel bespreek ik de verschillen tussen de concepten "spiritualiteit", "religie" en "geloof" en de onderlinge verbondenheid van deze dimensies van het geestelijke leven van de mens met onderwijs en opvoeding. Ik zal geen definities van deze concepten geven, maar naar hun kenmerken zoeken. Het doel van mijn artikel is te zoeken naar het intrinsieke verband van spiritualiteit met onderwijs en opvoeden.
\end{abstract}

1 Paper read at the Mini-conference in Gouda in January 2008, Prospects for Spirituality, Religion and Education. 
In mijn artikel werk ik een z.g. "religieuze matrix" uit waarin de kernvragen van spiritualiteit en religie te vinden zijn. Via deze matrix werk ik een visie uit op opvoeding (wel opgevoed zijn) en onderwijs en ik kijk naar hun intrinsieke relatie met spiritualiteit.

\section{Orientation}

There have been several discussions in theology, philosophy, psychology, cultural anthropology, social sciences and in quality of life research about how to define spiritual (McPherson, 2001; Caras, 2003). For some time now the discussion about the role of religion and spirituality in modern society has been going on in Dutch papers and media. Some even speak of the spiritual revolution (Heelas et al., 2005). In this discussion the term spirituality is becoming more and more important. Not only in Roman Catholic and Protestant circles, but also - and even more - in non-Christian circles. Whereas in the older discussions on spirituality, religion and faith, religion and belief systems were treated as separate but inter-dependent modalities. Nowadays a triad of spirituality, religion and belief systems emerges in which spirituality seems to be a novel and separate entity.

McPherson (2001:9) points to the fact that the meanings attached to the term spiritual vary considerably from one context to another. Analysis of spiritual qualities in science faces problems such as the imprecision of spiritual concepts, the subjectivity of spiritual experience, and the amount of work required to translate and map observable components of a spiritual system into empirical evidence.

Against the background of the growing pluralism of our times, it is difficult for modern man to find a kind of definition or working hypothesis which can be accepted by many scholars, believers of different religious orientation, et cetera and which can clarify the differences between the three mentioned entities. It is, therefore, interesting to see how the popular, free and democratic internet encyclopaedia Wikipedia tries to make a distinction which is similar to the content of the modern use of the concepts of spirituality and religion.

The unknown author of the article on spirituality (Anon., 2009) makes a distinction between spirituality in religion and spirituality as opposed to religion. This author writes:

In recent years, spirituality in religion often carries connotations of a believer having a faith more personal, less dogmatic, more open to new ideas and myriad influences, and more pluralistic than the doctrinal/dogmatic faiths of mature religions. It also can 
connote the nature of believers' personal relationship or 'connection' with their god(s) or belief-system(s), as opposed to the general relationship with a Deity as shared by all members of a given faith.

Those who speak of spirituality as opposed to religion generally believe meta-religiously in the existence of many "spiritual paths" and deny any objective truth about the best path to follow. Adherents of this definition of the term emphasise the importance of finding one's own path to whatever god there is, rather than following that which others recommend. Thus, the path which is most coherent becomes the correct one for oneself.

People of a more secular-spiritual disposition tend to regard spirituality not as religion per se, but as the active and vital connection to a force/power/energy, spirit, or sense of the deep self.

This Wikipedia-approach to the phenomena of spirituality and religion is, in my opinion, useful - not as a scientific "proof", but as a sign of the atmosphere of the actual popular discussion on spirituality, religion and faith.

\section{Trends in official literature on spirituality, religion and faith or belief system}

\subsection{Trends in theological literature}

The current increase in the use of the concepts spirituality, religion and belief system(s) is a modern phenomenon. In the standard lexicon, Die Religion in Geschichte und Gegenwart (1957-1965), spirituality is not even mentioned. There are, however, articles in this lexicon on Spiritismus, Spiritualen, Spiritualismus, and Religiöse Spiritualisten. Mostly, these concepts are not evaluated in a positive way. The article on "Spiritualen" (RGG, 1957-1965:3, 31074; cf. also RGG; 1957-1965:6, 253) is similar to what the Wikipedia author calls spirituality in religion. It speaks about the Ars Vitae of the Franciscan order, in which the rules of observance, poverty and humbleness are the leading rules of religious community life. In the Dutch Christelijke Encyclopedie (1956-1961) the concept spirituality is not mentioned either.

In a study of the Dutch reformed theologian, J.H. Bavinck, Religieus besef en Christelijk geloof (1989), the word spiritualiteit (spirituality) as such is not included. However, the concepts religie (religion) and religies besef (religious consciousness) that come close to the mo- 
dern use of the concepts spirituality and religion, can be found. When Bavinck answers the question, "What is religious consciousness?", he poetically writes: "That religious notion is therefore as the late sunset, when the sun has already undergone. It remains still long remembered." (Bavinck, 1989:9.) He also speaks of the "ijl religieus besef" (nebulous religious consciousness), or "het vage, algemene religieus besef" (the vague, common religious consciousness) (Bavinck, 1989:9); he furthermore uses the adjectives "vaag en schimmig" (vague and shadowy) (Bavinck, 1989:12). Bavinck makes an interesting distinction between "the vague and universal religious consciousness" and "concrete religions" (Bavinck, 1989:9).

In his formulation of the differences between the two sides of religious life, Bavinck points to the "fact" that the essence of religious consciousness is expressed by the intuition of the totality, the feeling and consciousness of the totality: the feeling of a cosmic community (Bavinck, 1989:23). The form, content and the concrete formulation of that feeling of the totality may vary. Its content, its notion of truth, is not transmissible (Bavinck, 1989:24). As suggested by Karl Rahner, what is necessary is a mystagogy (Rahner, 1939). Rahner writes: "Mystagogy is a process of initiation into the sacred, into the experience of the mystery of God." For Rahner, all forms of Christian initiation need a mystagogical dimension alongside the more doctrinal aspects (Rahner, 1975:402, 403; cf. Van den Berk, 1999:55). In accordance with Rahner, the Dutch theologian Van den Berk stresses the point that in the mystagogy the central task of the (religious) educator, the priest is seen as arousing and interpreting the interior of men (Van den Berk, 1999:55). The interior of men is meant spiritually rather than pistically. Here modern liberal Roman Catholic and modern liberal Protestants theology converge.

In Christelijk geloof, another formerly important reformed Dutch theologian, $\mathrm{H}$. Berkhof, analyses the characteristics of religion and faith. He also refrains from using the term spirituality (Berkhof, 1990:6-18). But, like Bavinck, he makes an interesting remark when he ends his summary of the (three) characteristics of religion: "Much men will be inclined to add a fourth element, that of the inner feeling, the mystic component of the religion." (Berkhof, 1990:8.) Berkhof's formulation serves to put the role of this fourth characteristic into perspective: "But this assumes a certain degree of individuality and, as a consequence an individual relation with the deity which is or was not common for all religions" (Berkhof, 1990:8).

It appears as if the idea of spirituality in modern Protestant theology is concentrated in non-orthodox circles. In reformational circles, it is 
possible to say that the reformational tradition is also a spiritual tradition, but merely in the sense that it is a spirituality of the normal everyday life, based on the idea of grace and Calvinistic common sense as a basic attitude and mistrust towards romantic idealism (cf. also Van Veen, 2009:27-33).

In the more liberal wing of the Protestant church, a variant of modern spirituality can be seen. It is called the solo religious people by the Dutch essayist Jan Oegema. In his discussion on "vague belief" and in the paper Trouw, Oegema introduced the term soloreligieus (solo religious person). These solo religious persons are individuals who nourish themselves religiously by reading. According to Oegema this turns them into a separate group of persons with a particular religious feeling within the anonymous army of men who "believe" in the existence of something. The solo religious people prefer the conjectural language of the poets, they like the blasphemy of romanciers, they prefer analysing essays and the renewing influence of philosophy - pure language. Solo religious people are generally spoken readers. The solo religious have turned away from organised religion, they mistrust the Articles of Faith, they know better what they do not believe than what they do believe. They do not, however, want to throw the Christian tradition overboard. A solo religious in a pew is like a tourist in his own fatherland (Oegema, 2006).

There are variations within the solo religious. For instance: a Spanisch author like María Zambrano and the Dutch minister Klaas Hendrikse are even discussing the possibility of having a destiny or belief of being minister although heaven is empty! Zambrano proclaims that we live in a historical period in which the sanct appears with an overwhelming power of the nothing (Zambrano, 1993; 2003), while Hendrikse is writing about "Belief in a God who does not exist", expresses a similar idea (Hendrikse, 2007). In her study, The great transformation, Karin Armstrong defends the idea of a return to the spirituality of the "Axial age" (words of Karl Jaspers) during which there was no theology or doctrine of the deities or deity (Armstrong, 2006). She remarks that compassionate spirituality leaves room for doctrine:

This is not to say that all theology should be scrapped or that the conventional beliefs about God or the ultimate are 'wrong'. The test is simple: if people's beliefs - secular or religious make them belligerent, intolerant, and unkind about other people's faith, they are not 'skillful.' If, however, their convictions impel them to act compassionately and to honor the 
stranger, then they are good, helpful, and sound. This is the test of true religiosity (...). Instead of jettisoning religious doctrines, we should look for their spiritual kernel. (Armstrong, 2006: Introduction.)

Heelas et al. (2005) write in their book, The spiritual revolution: why religion is giving way to spirituality, about the growing influence of spirituality in the Western world while Christianity, as an official belief system, is losing influence. ${ }^{2}$ Heelas et al. try to formulate a theory to explain the decline of religion and the possible growth of spirituality, or, as they call it: the "holistic milieu". They provide a theoretical perspective which explains both secularisation and sacralisation ${ }^{3}$ (Heelas et al., 2005: Chapter 4). The basic hypothesis of their proposed theory is the thesis of the subjectivating of modern life. Modern life or modern culture is moving up from life-as (determined, for example by religious authorities' vision of truth or formulated content of a faith-system) into the direction of what they call the subjective-life. In their theory the subjective-life is typified as the life in which every individual defines his/her own unique idea of meaning or spirituality. Their ideal is to live in accordance with their real, deeper I, Ego or Self (Heelas et al., 2005:81).

This book (Heelas et al., 2005) fits into the picture of what some writers on modern culture state that we live in a culture of experience, of feeling (Van der Kooi, 2005; Buijs, 2001; Hoogland, 2001). Van der Kooi defines this culture as: "The moment, today, the vitality of this moment, the enjoyment nów is the central point of orientation." In this culture of experience, a great deal of attention is paid to the body, the senses and impulses. But it is also a fact that in this modern type of experience culture there exists a new openness to that which goes beyond rational control.

It was Gianni Vattio who proclaimed a renewed openness to religious consciousness. He points to the fact that many modern thinkers claim that religious consciousness is an affair of pure feeling or that it is only possible to speak about God in silence - in terms of emptiness or nothingness, in terms of the Other (Levinas \& Ricoeur). In the famous words of Wittgenstein: "What I cannot speak

2 The conclusion reached by Heelas et al. (2005) is dramatic: Christianity will be eclipsed by spirituality in this country within the next 20 to 30 years. Many people believe that this "New Romantic" movement will prove more significant than the Protestant Reformation of the sixteenth century. 
about I must pass over in silence." (Wittgenstein, 1998: proposition 7.) Vattimo makes the interesting remark that today there seems to be no serious reasons for philosophy to keep silent about God. Vattimo infers a logical consequence: if it is true that the great histories have disappeared and if it is true that all of the arguments of rationalistic philosophies have failed, "then is it no longer possible to think that God does not exists because $\mathrm{He}$ is not scientifically proofable" (Vattimo, 2002:91). In his way Vattimo makes room and sees room for the idea of religion and fate in the contemporary debate. 4

\subsection{Trends in non-theological literature}

In the non-theological scientific literature certain trends emerge in the discussion about definitions of spirituality and religion that originated in the studies of Allport (1966) as well as Allport and Ross (1967). This trend seems to be not a content-approach, but a more functional approach to the spiritual and to religion. It is functional in the sense that the question is asked regarding the role spirituality and religion play in the mental and social life of man, in man's development to maturity and in his/her formulation of his/her personal vision of life.

Allport and Ross (1967) conclude that the spiritual is a subjective experience and that it points to an orientation towards both intrinsic and extrinsic religiousness. In terms of the former, religion is viewed as something deeply personal to the individual. It is often defined as "persons living their religion" (Allport, 1966; Allport \& Ross, 1967). An individual's extrinsic orientation towards religion, on the other hand, places emphasis on religion as membership of a powerful ingroup (Genia \& Shaw, 1991) that can provide protection, consolation and social status (extrinsic-personal - Allport \& Ross, 1967), can allow religious participation, refer social status (extrinsic-social Allport \& Ross, 1967), or provide the use of mechanisms of ego defence. In the Quality of Life Research circles much research has been done with respect to the relationship between the spiritual dimension of human beings and their preception of happiness, seen

4 The position of Vattimo is quite different from that of Wittgenstein, Ricoeur or Levinas. Vattimo supposes that to speak about God is possible, but that philosophical atheism was only a reaction against "the moral God" as Nietzsche already made clear. Still, Vattimo sees a possibility for a more contemporary approach to God, faith and religion. 
from both the intrinsic and the extrinsic sides of religious life (Lewis et al., 2004).

Based on Erik Erikson's psychosocial and developmental perspectives and George $\mathrm{H}$. Mead's symbolic interactionism, the human being's sense of spiritual identity can be regarded as responsible for the mediation of life's ultimate questions (Erikson, 1950; cf. also Mead, 1934). Erikson considers religion to be important since it forms part and parcel of successful and healthy personality development. Religion is also seen as the primary instrument through which cultures promote the virtues associated with each stage of life. Religious rituals facilitate this process.

Erikson is, however, not the only psychologist that entertained a positive view of the function of religion(s). William James (1902), Carl Jung (1938), Ana-Maria Rizzuto (1979), James Fowler (1981), Fritz Oser and Paul Gmünder (1991), Fritz Oser, George Scarlett and Anton Bucher (2006) all wrote about the spiritual development of children which they saw as a necessity for healthy personality development. Fromm (1955) was convinced that human beings need a stable frame of reference and that religion meets this need. Only religion seems to have answers to the fundamental questions of life. 5

The answers to existential questions are not just part of a whimsical or metaphysical game people play. All the psychologists mentioned above stress the functionality of spiritual/religious questions and answers. The answers provide a person with existential security or a subjective feeling of basic security as psychologists call it. Each person is in need of such basic security. Maslow called it a safety need. The spiritual aspect or dimension of being human satisfies this need. Basic security can, therefore, be seen as an aspect of the inner subjective side of a person's appreciation of his/her life. It is the outcome of all the answers a person subjectively gives with respect to all the essential life-questions.

In a psychological way, you can call rest basic security, love, attachment, mental sanity, property, et cetera, the personal conditions for meaning. It is thus possible to refer to Maslow's hierarchy of needs as the necessary quality conditions for the experience of happiness, meaning or sense in life. Furthermore, Fromm's (1955) formulation

5 Although Erikson's theory remains influential in the psychological study of spiritual development, it has not been evaluated empirically. 
of the five universal psychological basic needs of man are universal needs which can be found in several of the previously mentioned spiritual and religious aspects as well as in the spirituality matrix described later in this article.

The five basic universal needs are:

\section{- $\quad$ The need for relatedness}

As human beings, we are aware of our separateness from each other and seek to overcome it. Fromm calls this our need for relatedness and views it as love in the broadest sense (Fromm, 1955: 37). This need allows us to transcend our separateness without denying our uniqueness.

\section{- $\quad$ The need for creativity}

Fromm (1955) states that everybody desires to overcome and transcend an unpleasant fact of being human: the sense of being passive creatures. Man wants to be a creator. There are many ways to be creative: we give birth, we plant seeds, we make pots, we paint pictures, we write books, we make music, we love each other. Creativity is, in fact, an expression of love.

\section{- $\quad$ The need of rootedness}

Man needs roots. He needs to feel at home in the universe, even though, as human beings, we are somewhat alienated from the natural world. In order to cope in the difficult world of adulthood, man needs to find new and broader roots than family ties alone. Man needs to discover brotherhood within humanity.

\section{- $\quad$ The need for a sense of identity}

"Man may be defined as the animal that can say 'l'." (Fromm, 1955:62.) Fromm believes that man needs to have a sense of identity, of individuality, in order to stay sane. In spite of this need, everyone is a still a member of a social circle. Thus, there exists perpetual tension between individuality and social belonging. Nevertheless, the need for identity is ever present.

\section{- $\quad$ The need for a frame of orientation}

This need is based on the fact that man needs to understand the world and his/her place in it. The society of man, especially the religious aspects of culture, often attempts to provide man with such a religious understanding. Myths, philosophies, the great histories of cultures, sciences and the like provide man with orientation and 
structure in his existence. Fromm (1955) claims that man needs a frame of orientation. When such a frame of orientation is lacking, almost anything will do - even a bad one is better than no frame of orientation! If man does not have an explanation at hand, he/she will make one by means of rationalisation. Man wants a frame of orientation that provides him with meaning. He does not only want understanding, but a special quality of understanding: a warm, firm and human understanding (Fromm, 1955).

In conclusion it can be said that the concepts spirituality, religion and faith can be typified on the basis of their content aspect. Moreover, they can be studied on the basis of their functional aspects in the social, psychological, educational, moral realm and life-orientation aspects in the spiritual, religious and fate aspects of man's life. There is a modern tendency to be spiritual, to be a believer without the traditional faith content. Most of these studies conclude the necessity of a spiritual orientation or basis in man's existence and development.

\subsection{Differences between spirituality, religion and faith (systems)}

In the actual discussion on the modern way of living out one's spirituality, concrete spirituality can have many faces. But despite all these faces, the central characteristics of spirituality has to do with inner feeling processes directed to someone or something, often with a mystical impact. I think that Schleiermacher's Gefuhl and Anschauung des Universums (Schleiermacher, 1799), but also Tillich's "experience of the unconditional", (Tillich, 1963:4) are related to what is nowadays called the spiritual. I agree with the description of the main focus of spirituality as distilled from the words of Bavinck and Berkhof: "religion has to do with the awareness of the Totality" (Bavinck, 1989:12) or the "relation to the Absolute" (Berkhof, 1990: 6 ). These descriptions are true for both spirituality and religion. The difference between them has to do with the difference between the pre-theoretical and the theoretical (see Section 3 in this article).

In his account of the content of the religious consciousness, Bavinck states that there are five characteristics (Bavinck, 1989:12-75) that typify the "religious consciousness", namely:

- the perception of the totality, the intuition of the universal;

- the normative awareness;

- the commitment to a Higher Power; 
- the delivering of the evil, a need for a Saviour; and

- the wish to be free of the tension between living his/her own life and the fatum, or fate.

Berkhof states that, despite all the differences in content between the religions, their structural aspects still "show a great deal of uniformity" (Berkhof, 1990:8). Berkhof indicates three structural similarities. Most of the religions have "a mythic element, a doctrine or a proclamation" (the way in which the absolute opens up), the element of the rite or cult (the response of men), and the moral rules (the consequences of "knowledge" and salvation for everyday life). The systematisation is different, but the existential "motives" are structurally the same. It is important to note the fact that spirituality and religion both have consequences for the everyday lives people live.

Looking at the etimology of the word religion, complicates a definition of the concept. The famous reference guide, Religion in der Geschichte und Gegenwart, indicates that there are several approaches for looking at the phenomenon religion and that all these approaches underline different aspects of the phenomenon. The theological manual defines religion as an "erlebnishafte Begegnung mit heiliger Wirklichkeit und als antwortendes Handeln des vom Heiligen existentiell bestimmten Menschen" (RGG, 1956-1965:5, 961). This definition implies that, in all religions, the structural content is inherently present in the human relation with the sacred. The relation with the sacred and the answer of man to the sacred are thus identified as the essential elements of religion. The way in which people relate to the sacred varies. According to RGG, "[t]he archetype of this relation is the religious experience" (RGG, 19561965:5, 963). RGG warns not to reduce "experience" to "feeling". "Erlebnis ist eigentlich ein Ergreifen eines Objektes mit dem ganzen Leben, so daß das Ergriffene das eigene Leben erfüllt und existentiell bestimmt." (RGG, 1956-1965:5, 963.) On this point the etymology of the word religion opens up an important connotation of the concept: "religion" stems from the Latin 6 word religare which means:

6 Several Roman authors give the following etymologies of the word religio: Cicero deduces the word from relegere (read again, repeat, diligently observe) and typify with that the term religion as continuously and diligently observe of everything that is related to the worship of the gods (Cicero, De natura deorum II. 28 and De inventione II. 22 and 53). Lactantius explains religion from religare (bind again, well bind) and understands under religion the link (liga) between god and people (Lattantius, Divinae Institutiones IV. 28). Aulus Gellius infers the term from relinquere (leave behind) and points to the fact that all that belongs to the religion of the profane has been separated (Gellius, Atticae IV. 9). Augusti- 
(relig(āre) to tie, fasten (+ ligāre) to bind, tie. A person or a group ties him-/her-/itself to the experienced sacred. This will not be done if there is no feeling of being at home or at ease with this sacred.

The difference between spirituality and religion is not their "object" (the sense of the universal, the absolute; although, the sense of the sacred is more developed in religion), but the degree of rational systematisation of concepts and systematic approaches to what is felt as the universal or the absolute. Spirituality exists in a more pretheoretical way: it can be lived out as a pre-theoretical feeling, sense or idea for example something must exist, life cannot be senseless, et cetera. Religion is a more rational (I do not say is rational!) system. The content of religion can - to a certain level - be formulated in the forms of myths, tales, in written (holy) books as well as in formulations that resemble doctrines. In religion, man "knows" to name the absolute. 7 Man has a notion of what the sacred means for the lives of mankind; man "knows" how to behave morally well. Religion does not, however, presuppose theology. Theology is the higher/highest level of rationality at which faith systems are formulated. Faith is based on spirituality and religion, but has a story to tell about the absolute, the universal or sacred and these stories become theology when they are systemised in rules, doctrines, creeds or dogmatics.

Of course there is no strict division or partition between these three concepts; they have characteristics of their own, but are intertwined. Although you can be spiritual without adhering to any religion or faith, you cannot have a faith without a religious foundation. Religion needs a spiritual basis.

nus connects the word with re-eligere (to choose again; to prefer): in the religion man chooses his God, Whom he had lost by sin, as a source of his salvation (Augustinus, De civitate Dei X, 4; cf. also Origin: 1150-1200; ME religioun (< OF religion) < L religiōn- (s. of religiō) conscientiousness, piety, equiv. to relig(āre) to tie, fasten (re- RE- + ligāre to bind, tie; cf. LIG AMENT) + -iōn- -ION; cf. RELY.) The etymological deduction from religare, relinquere, re-eligere meet linguistic and lexicological objections. The most prominent authority has the conception of Cicero: religion refers to apprehension compared with the god-driven (god fruit, agreement; German: "Gottesfurcht"; Jew: jir'at ha-Sjem) and from that the resulting observation of the cults of the deities.

7 Even as the absolute, the sacred has many names (Islam, Christianity); when you may not give it a name (Jewish vision of God), you still have the opportunity to say something about it in religion. 
Tabel 1: The pre-theoretical and the theoretical with respect to spirituality, religion and faith

\begin{tabular}{|l|l|}
\hline Spirituality & Pre-theoretical "thinking" \\
\hline Religion & Theoretical thinking \\
\hline Faith (systems) & Theoretical thinking \\
\hline
\end{tabular}

\section{The pre-theoretical and the theoretical}

The distinction between the pre-theoretical and the theoretical must be introduced: it constitutes the distinction between intuition, common sense and systematic thinking. Dooyeweerd developed a systematic view of man's pre-theoretical and theoretical attitude (Dooyeweerd, 1969). The similarities between Dooyeweerd's vision of the pre-theoretical and theoretical attitude and the definitions of spirituality, religion and faith found in this article, will be highlighted. According to Dooyeweerd the pre-theoretical attitude offers man the following:

- A grasp on reality. Everyday life "is systatic 8 and grasps reality as reality offers itself" (Dooyeweerd, 1969:36).

- Experience of things. In everyday experience, I encounter things that persist as those same things until they lose their identity (Dooyeweerd, 1969:3-4).

- No separation. Everyday experience does not separate noumenon (thing in itself) from phenomenon (our experience or knowledge of it). This does not imply a form of naïve realism, but the experience that in everyday life man does not separate the aspects of reality. Life is experienced as a whole. The so-called everyday attitude is a non-theoretical attitude.

- The everyday experience is direct, immediate engagement. "For the very essence of the naïve attitude appeared to be that in it thinking lacks the theoretical Gegenstand-relation." (Dooyeweerd, 1969:36.)

- Everyday experience is integral. That means it is related to everyday life and experiences. The world is experienced as a

8 Systatic: Dooyeweerd (1969: 36, footnote 1) explains: "The reader will remember that this obsolete word is meant to indicate the factual immediacy of our integral experience of reality." 
whole, a diverse whole that is nevertheless integral. In this way, it is opposed to the theoretical attitude which attempts to split life and reality apart into separate spheres (Dooyeweerd, 1969:2829).

- Man does not theorise about everyday life; everyday life is "incapable of being comprehended theoretically" (Dooyeweerd, 1969: 36). If the theoretical attitude is taken as something the I "stands over against" (Gegenstand), everyday life is not something that the I can "stand over against" in like manner. Hence, I can never generate a complete theory of reality, Dooyeweerd warns: everyday experience is not inferior to theoretical thought. 9

- Another important thing to stress is Dooyeweerd's remark on the social aspect of the pre-theoretical. In Dooyeweerd's opinion it is a mistake to think of everyday experience in primarily individual terms. It has an important social aspect: "Naive experience is doubtless first formed by social praxis." (Dooyeweerd, 1969:32.) In this social praxis, a great deal of influence is exerted by the religious standpoint of the culture/sub-culture. "Naïve experience is not neutral with respect to the religious position of the I-ness." (Dooyeweerd, 1969:29.)

It is clear that the spirituality fully possesses the characteristics found in the pre-theoretical attitude. Religion is a go-between between the pre-theoretical and the theoretical attitude. Faith is like the theoretical attitude (like, not in full!).

\section{The relation between spirituality and the bringing-up or education of children}

Looking back to what has been postualted about spirituality, religion and faith, there are some traits which have to be worked out within the realm of the education and bringing-up of children:

- The intuition of the totality, the feeling and consciousness of the totality or a cosmic community feeling: the form and style in which this intuition and feeling of unity are systematised, differ across historical times and cultural locations.

9 "Naïve experience may be deepened through scientific knowledge, but cannot be destroyed by it." (Dooyeweerd, 1969:3.) 
- The notion of truth about spirituality, religion and faith is not really transmissible. The claims of their truths can only be lived out/or shared in a kind of mystagogy.

- There is an element of inner feeling - the mystic component of the religion.

- All (though more in the case of religion and faith) have consequences for the inner and the outward (e.g. the social and moral) life of man.

- Spirituality, religion and faith play a role in finding basic security in life and in forming the ego-identity of children while growing up. The basic security is also sought in the wish to be freed of the tension between living his/her own life and a formulated fate along with its consequences for a Christian or Islamic life.

- There is an intuitive sense of the universal, the absolute or the sacred. This is mostly true of the pre-theoretical side of spiritual and religious life. The other side of the picture is the theoretical systematisation of religion - where religion is becoming a formulated faith or doctrinal system.

- Spirituality, religion and faith are dependent on the social context in which they exists or function. As cultural historian William Irwin Thompson states: "Religion is not identical with spirituality; rather religion is the form spirituality takes in civilization." (Thompson, 1981:103.)

- Spirituality, religion and faith all have to do with finding, feeling, constructing, intuiting, learning, handing over meaning.

Although the essence of the three concepts at stake cannot be worked out in full within this article, it is still good to take note of what the RGG says. There are several scientific approaches to these phenomena; each of these approaches highlights different characteristics of the phenomena (RGG, 1957-1965:5, 968-970). There are also differences in the approaches to theology, philosophy, sociology, psychology and cultural antropology. In my opinion these different (but not entirely separate) approaches are also significant for the theorist of education and pedagogical bringing-up. That, however, would lead too far away from the present topic.

The following is of importance: in our times faith, in the historic doctrinal form found in traditional churches, is less dominant in modern man's life as a frame of orientation than in earlier times. In Europe one detects a growing spiritual orientation which is not 
automatically connected with traditional churches. The spiritual, religious and fate activities of man, also of modern man, are, fundamentally, ways of finding a spiritual quality to life, ways of making oneself at ease or at home in life. The spiritual movements of our times are forces which give man orientation in life. Bringing-up and schooling both have to do with providing the educatees with orientation in life and introducing them to meaning. Here spirituality, religion and fate meet each other, but each on its own terms.

The next section is an elaboration on the intertwinement of spirituality, religion, faith, bringing-up and education.

\section{The intrinsic spiritual motivation: a spirituality matrix}

To elaborate the view that it is necessary to attend to the spiritual aspect of life as the basis on which a person's basic security and, as a consequence, his basic notion of how to live rests, I propose a socalled spirituality matrix. This matrix elucidates the inner/internal qualities-life results dichotomy (Valenkamp \& Van der Walt, 2006) inspired by the work of Ruud Veenhoven (Veenhoven, 1984 \& 2000). It is also based on the outcome of a study on the basic questions to which religions, theologies and philosophies have given answers to in history (Van der Burg, 1984). The matrix is useful for several reasons. One of these reasons is that empirical research can be done in terms of the contents of each cell of the matrix. 


\section{Tabel 2: The spirituality matrix}

\begin{tabular}{|c|c|c|c|c|c|}
\hline $\begin{array}{l}\text { Relationall } \\
\text { Spiritual }\end{array}$ & Myself & Others & Nature & Culture & $\begin{array}{l}\text { Tremendum/ } \\
\text { fascinosum }\end{array}$ \\
\hline $\begin{array}{l}\text { Unhappiness/ } \\
\text { Evil }\end{array}$ & $\begin{array}{l}\text { Why do I live; } \\
\text { What do I live } \\
\text { for? } \\
\text { (Questions } \\
\text { about the es- } \\
\text { sence of life.) } \\
\text { (Note: intersec- } \\
\text { tion between } \\
\text { "Myself" and } \\
\text { "Unhappiness/ } \\
\text { Evil") }\end{array}$ & $\begin{array}{l}\text { How and why am } \\
\text { I different from } \\
\text { others and how } \\
\text { do I relate to } \\
\text { them? } \\
\text { (Questions about } \\
\text { tensions with } \\
\text { others, the power } \\
\text { of others over } \\
\text { me/manipulation.) }\end{array}$ & $\begin{array}{l}\text { Did I come into } \\
\text { existence by ac- } \\
\text { cident or was I } \\
\text { intentionally cre- } \\
\text { ated (by intelli- } \\
\text { gent design)? } \\
\text { (Questions about } \\
\text { nature and eter- } \\
\text { nal repetition.) }\end{array}$ & $\begin{array}{l}\text { Do I (have to) } \\
\text { work as a duty or } \\
\text { as a pleasure? } \\
\text { (Questions about } \\
\text { power, obe- } \\
\text { dience, struggle, } \\
\text { responsability } \\
\text { and peace.) }\end{array}$ & $\begin{array}{l}\text { Do I experience in- } \\
\text { finite cosmic emp- } \\
\text { tiness, the silence } \\
\text { of the divine, or the } \\
\text { cosmic fullness of } \\
\text { a life in tune with } \\
\text { the divine? } \\
\text { (Questions about } \\
\text { religion, violence, } \\
\text { death, eternal life, } \\
\text { resurrection and/or } \\
\text { reincarnation.) }\end{array}$ \\
\hline $\begin{array}{l}\text { Happiness/ } \\
\text { The Good/ } \\
\text { Salvation }\end{array}$ & $\begin{array}{l}\text { Am I feeling at } \\
\text { home or at ease } \\
\text { with myself? } \\
\text { (Questions } \\
\text { about self-confi- } \\
\text { dence and per- } \\
\text { sonal identity.) }\end{array}$ & $\begin{array}{l}\text { Am I seen and } \\
\text { heard and appre- } \\
\text { ciated? } \\
\text { (Questions about } \\
\text { friendship, love, } \\
\text { sexuality, etc.) }\end{array}$ & $\begin{array}{l}\text { What is my re- } \\
\text { lationship with } \\
\text { nature and its } \\
\text { beauty? } \\
\text { (Questions about } \\
\text { my relationship } \\
\text { with nature and } \\
\text { my surround- } \\
\text { ings.) }\end{array}$ & $\begin{array}{l}\text { What should be } \\
\text { my place in } \\
\text { society? } \\
\text { (Questions about } \\
\text { creativity in art, } \\
\text { science and } \\
\text { knowledge, and } \\
\text { about one's so- } \\
\text { cial position and } \\
\text { social apprecia- } \\
\text { tion.) }\end{array}$ & $\begin{array}{l}\text { How do I come } \\
\text { into contact with } \\
\text { the holy or divine? } \\
\text { (Questions about } \\
\text { the great (holy) } \\
\text { histories (conso- } \\
\text { lation and insight- } \\
\text { giving stories), me- } \\
\text { ditation and all } \\
\text { forms of contact } \\
\text { with the holy or } \\
\text { divine world, soli- } \\
\text { darity and religious } \\
\text { rites.) }\end{array}$ \\
\hline $\begin{array}{l}\text { Transcendence/ } \\
\text { Immanence }\end{array}$ & $\begin{array}{l}\text { What is my } \\
\text { identity and what } \\
\text { feelings do I } \\
\text { have about my- } \\
\text { self? } \\
\text { (Questions } \\
\text { about the type of } \\
\text { person I am for } \\
\text { myself.) }\end{array}$ & $\begin{array}{l}\text { How do I see } \\
\text { other people, and } \\
\text { what do they } \\
\text { mean to me? } \\
\text { (Questions about } \\
\text { the meaning of } \\
\text { others for me (my } \\
\text { visions of per- } \\
\text { sons and groups } \\
\text { that I know).) }\end{array}$ & $\begin{array}{l}\text { What does na- } \\
\text { ture mean to } \\
\text { me? } \\
\text { (Questions about } \\
\text { the meaning of } \\
\text { nature to me.) }\end{array}$ & $\begin{array}{l}\text { What does the } \\
\text { culture of my } \\
\text { group or society } \\
\text { mean to me? } \\
\text { (Questions about } \\
\text { the meaning of } \\
\text { the culture of my } \\
\text { group or society } \\
\text { to me.) }\end{array}$ & $\begin{array}{l}\text { What does the } \\
\text { Holy or Divine } \\
\text { mean to me? } \\
\text { (Questions about } \\
\text { the spiritual as- } \\
\text { pects of my life.) }\end{array}$ \\
\hline $\begin{array}{l}\text { Right/ } \\
\text { Wrong }\end{array}$ & $\begin{array}{l}\text { How can I cope } \\
\text { with the good } \\
\text { and the evil in } \\
\text { my life? } \\
\text { (Questions } \\
\text { about coping } \\
\text { with right and } \\
\text { wrong in my } \\
\text { own life.) }\end{array}$ & $\begin{array}{l}\text { How can I cope } \\
\text { with the good } \\
\text { and the evil in the } \\
\text { lives of others? } \\
\text { (Questions about } \\
\text { coping with right } \\
\text { and wrong in the } \\
\text { lives of others.) }\end{array}$ & $\begin{array}{l}\text { How can I cope } \\
\text { with the good } \\
\text { and the evil in } \\
\text { nature? } \\
\text { (Questions about } \\
\text { coping with right } \\
\text { and wrong in } \\
\text { nature.) }\end{array}$ & $\begin{array}{l}\text { How can I cope } \\
\text { with the good and } \\
\text { the evil in culture? } \\
\text { (Questions about } \\
\text { coping with right } \\
\text { and wrong in } \\
\text { culture.) }\end{array}$ & $\begin{array}{l}\text { How can I cope } \\
\text { with the good and } \\
\text { the evil in the } \\
\text { spiritual dimension } \\
\text { of my life? } \\
\text { (Questions about } \\
\text { coping with right } \\
\text { and wrong in } \\
\text { religious/spritual } \\
\text { context.) }\end{array}$ \\
\hline
\end{tabular}


A basic feature of the spirituality matrix is that it starts from the fundamental human relations. The matrix leaves it to every person to define, on the basis of these fundamental relations, his/her personal way of life. The relations have been organised under the headings of myself, others, nature, culture and the "tremendous" or the "fascines". In all of these relations, a person can encounter happiness (the good) and unhappiness (the evil), the immanent as well as the transcendent, and also decide what is morally right or wrong in terms of each of the relations. Each of the cells of the matrix represents an intersection between a column and a row, and contains a primordial question that people tend to ask in life.

\subsection{Discussion}

The spirituality matrix reflects two fundamental aspects of human existence, namely relational aspects (myself, others, nature, culture, the tremendous and the fascinating - the headings of the columns), and the spiritual (unhappiness/evil; happiness/the good/salvation; transcendence/immanence; and right and wrong - the left hand column). Van der Burg (1984:226, 230, 233, 55) calls the latter basic theological principles. Whether one accepts his view or not will depend on how one defines the concept theos in theological. Do we have to interprete the word theos ontically, as is always done in the Christian, Islamic, Jewish and other religions and doctrinaire faith systems? Or in a more symbolic, mystical way? By annexing the theos for one's own religious community and religiously inspired culture, one will be inclined not to see that other persons or cultures had and have the same need for discovering answers to the fundamental or ultimate questions of life. It will also be difficult for such people to understand that all human beings from all cultures and throughout all times have constantly asked these and similar questions. The answers people formulated in their quest for meaning helped to provide them with perspectives on what came to be regarded as the theos or as a good idea about the meaning of life.

Because educational research - to be a science and not only a philosophy or theology of education - has to transcend religious diversity as well as potential religious tensions, the principles contained in the left hand column of the matrix ought not to be regarded as theological. This is because theology is a theoretic affair (see the discussion on pre-theoretical and theoretical in this article). It is preferable to regard them as pre-theoretical, spiritual or pistic principles. These spiritual or pistic principles function as 
special modi of interpretation with respect to the relations contained in the spirituality matrix (cf. the headings of the columns). The cells of the matrix contain examples of the fundamental or ultimate questions which people, in their quest for meaning, tend to ask themselves and others. Man is always looking for, or constructing meaning for his life. Education has to provide new generations with the drive to search for meaning and the tools to find or construct meaning. In this way, the spirituality matrix is helpful in pointing to the central aspects of meaning, which, in education and bringing-up, has to be systematised by the educatees with aid of the educator. The contents of the cells, however, do not supply answers to such questions about meaning. They do not even suggest the religious direction of the answers for Christians, Muslims, Jews, Humanists, et cetera. Each person has to find his/her own answers to the questions formulated in the cells. Refusal to search for answers to questions such as these will put a person's perspective on the meaning of life and/or personal happiness at risk.

The value of this matrix is that it facilitates empirical research about subjective constructs such as spiritual consciousness, religious feelings and faith. This research can help educators to discover empirical relations between the different structural aspects of these concepts and other aspects of people's thinking, feeling, doing, and wishing in relation to each other, as well as the relation of these concepts to education and the bringing-up of children. The matrix also allows every individual, culture or society to define for her-/him-/ itself the form and content of what ideally constitutes a good vision of the aims, values and norms in education and bringing-up.

In the next section the connection between the education and upbringing of children on the one hand and spirituality, religion and fate on the other hand, will be discussed. The connection is to be found in the concept of to be well educated.

\section{The criterion of being well educated}

To be well educated is a concept that has both a subjective or inner side as well as a more objective structural and cultural side. The latter refers to the product character of education (Imelman, 1995:45). The educator, the education system and the school aim at achieving those "features of a worth-while form of life any educator thinks it most important to foster" (Peters, 1975:17). People themselves, as well as their society, must either appreciate or reject the proposed definition of a well educated person. The same applies 
for the lifestyle associated with that definition, a lifestyle that can be observed in the conduct of a supposedly well educated person.

The lives of well educated people have to comply with the criterion of what it means to be well educated according to their particular society. I encountered such criteria in the educational work of R.S. Peters $(1967 ;$ 1975). He concluded that a well educated person has to show that he/she was - to a certain extent - competent in the following educational areas (outcomes/competencies; or in Nussbaum's terminology: capabilities (Nussbaum, 2000; 2006); equipped for successfully performing a set of tasks, inter alia those associated with some profession; possessing a conceptual/cognitive scheme that is more than only a collection of facts and knowledge; having some understanding of the reason why things exist or happen; possessing an attitude of openness to criticism; understanding that life is not perfect; seeing that a particular form of life - as exhibited in people's conduct, the activities to which they are committed to or deliberately reject - is based on personal judgements and feelings thought by them to be desirable or meaningful; understanding that the well educated person must be able to account for what he/she knows, wants and does. A well educated person has to be openminded, prepared to incorporate new knowledge into his/her existing store of knowledge (Piaget's accommodation and assimilation).

The educated person also has to see and feel that he/she has been equipped to do the things he/she wants to do, that his/her way of life displays some mastery of forms of thought and awareness that are not harnessed purely to utilitarian or vocational purposes or completely confined to one mode of activity. A well educated person, finally, has knowledge and understanding that makes a difference to his/her general view of the world, his/her actions in and reactions to it, and shows respect for the standards immanent in forms of thought and awareness, as well as the ability to attain them (Peters, 1967:9).

In the 1960 s and 1970s Peters was already working with a competence or outcomes-based model of education, but founded his approach on a much deeper spiritual basis than these modern approaches. Answers to the why? of a person's lifestyle come from deeper levels of humanity than only the utilitarian or vocational facets of human existence. They flow from the spiritual dimension of humanness. That is why the adoption of Imelman's definition is of value. He defines education as an introduction into meaning under the aspect of a relevant and anthropological justification (Imelman, 1995:25). Education and bringing-up have to do with meaning, 
sense, with finding and systematising (more or less) a lifevision. But not only that: man has to keep their feet on the ground. The concept of being well educated combines the meaning aspect and the realistic aspect.

Tabel 3: Matrix for education/schooling

\begin{tabular}{|l|l|l|}
\hline & Outer Qualities & Inner qualities \\
\hline Life changes & Facilitating & Drive \\
\hline Life results & Societal relevance & To be well educated \\
\hline
\end{tabular}

Peters' concept of being well educated includes formal indicators or criteria for competencies or outcomes in education. These indicators can be applied by educators as criteria for developing educational ideas and curricula, but they should not be applied in a manner that will deprive learners/students from the freedom and the possibility of using them in a way appropriate for them as individual human beings.

In the educational matrix, (Table 3 ) the column headed "Inner qualities" contains the anthropological elements of the educational quality concept. "Life-ability of the person" and "subjective appreciation of life" refer to the results of a conceptual analysis of the concept of being well educated. The notion of being well educated contains a claim of universal validity while, at the same time, it reflects a degree of subjective personal significance as well as the cultural and subcultural justification for such significance. The concept of being well educated in itself is a subject for theological and philosophical investigation and clarification. Empirical research can, however, also be done on the structural aspects of what exactly belongs to the quality of being well educated in the education matrix that I proposed above.

There is one more aspect of this matrix of inner/internal aspects combined with life-results (i.e. to be well educated) that still needs attention. These inner qualities also have a spiritual side or dimension. In saying this, I underline my conviction that the quid est homo? question cannot be adequately answered without bringing the spiritual dimension of being human into connection with this anthropological question. A person's subjective vision of meaning or quality of life and/or subjective well-being has everything to do with the spiritual aspect of being human. Researchers such as McPherson (2001), Caras (2003), Lewis et al. (2004) recognise the con- 
nection between the spiritual dimension of the human being and the criteria of being well educated.

\section{Concluding remark}

Despite the fact that it refers to virtually undefinable concepts such as spirituality, religion and fate, the proposed spirituality matrix opens up possibilities for interpreting spirituality and religion. The results of such interpretations are obviously only valid or useful for a specific point in time and/or place and for a certain cultural and social design. People constantly discard existing interpretations because humanity is always searching for ultimate meaning or truth, even for the ultimate meaning or truth. Man does not possess the cognitive ability to define for once and for all the ultimate truth. Because of this, man is constantly involved in a quest for the ultimate meaning.

The concept of being well educated has to do with some of the results of the individual quest for meaning of the educatees. Education has to guide the learners in their search for what they will regard as meaningful, as the sense of life, as happiness, as his/her ultimate truth or value. The broader society has to provide the external conditions and support to enable them to do so successfully. In being well educated and in participating in the quest for meaning, men may meet each other in their shared inherent spiritual basis of the personality of well educated young people.

\section{List of references}

ALLPORT, G.W. 1966. The individual and his religion: a psychological interpretation. New York: Macmillan.

ALLPORT, G.W. \& ROSS, J.M. 1967. Personal religious orientation and prejudice. Journal of personality and social psychology, (5):432-433.

ANON. 2009. Article on spirituality. http://en.wikipedia.org/wiki/Category: Spirituality Date of access: 3 Mar. 2009.

ARMSTRONG, K. 2006. The great transformation: the beginning of our religious traditions. New York: Knopf.

AUGUSTINUS. 1992. De stad van God (De civitate Dei). Vertaald en ingeleid door Gerard Wijdeveld. 3e dr. Baarn: Ambo.

BAVINCK, J.H. 1989. Religieus besef en Christelijk geloof. Kampen: Kok.

BERKHOF, H. 1990. Christelijk geloof. Nijkerk: Callenbach.

BUIJS, G. 2001. Opkomst belevingscultuur is ondergang van beleving. Beweging, Mar. 2001.

CARAS, C. 2003. Religiosity/spirituality, and subjective wellbeing. Melbourne: Deakin University.

DOOYEWEERD, H. 1969. A new critique of theoretical thought. Phillipsburg: Presbyterian and Reformed Publishing. 
ERIKSON, E. 1950. Childhood and society. New York: Norton.

FOWLER, J.W. 1981. Stages of faith: the psychology of human development. San Francisco: Harper.

FROMM, E. 1955. The sane society. Holt McDougal: New Work

GENIA, V. \& SHAW, D.G. 1991. Religion, intrinsic-extrinsic orientation, and depression. Review of religious research, (32):274-283.

GROSHEIDE, F.W., LANDWEHR, J.H., LINDEBOOM, C. \& RULLMANN, J.C. eds., 1926-1929. Christelijke encyclopaedie voor het Nederlandsche volk. 6th ed. Kampen: Kok. (Supplement en Register. 1931. Christelijke Encyclopedie. F.W. Grosheide \& G.P. van Itterzon. 2nd revised edition. Kampen: Kok. 1956-1961.

HEELAS, P., WOODHEAD, L. \& TUSTING, K. 2005. The spiritual revolution: why religion is giving way to spirituality. London: Blackwell.

HENDRIKSE, K. 2007. Geloven in een God die niet bestaat: manifest van een atheïstisch dominee. Nieuw Amsterdam: Uitgevers.

HOOGLAND, J. 2001. Van overlevingsgeloof naar belevingsgeloof. Beweging. Mar. 2001.

IMELMAN, J.D. 1995. Theoretische pedagogiek. Utrecht: Nijkerk. (Theoretical pedagogics.)

JAMES, W. 1902. The varieties of religious experience. New York: Penguin.

JUNG, C.G. 1938. Psychology and religion: the Terry lectures. New Haven: Yale. (Psychology and religion: West and East collected works, Vol. 11.)

LEWIS, C.A., MALTBY, J. \& DAY, L. 2004. Religious orientation, religious coping and happiness among UK adults. Elsevier personality and individual differences 38(5):1193-1202.

MCPHERSON, W. 2001. Spirituality and well-being. Melbourne: Deakin University.

MEAD, G.H. 1934. Mind, self, and society. Ed. by C.W. Morris. Chicago: University of Chicago.

NUSSBAUM, M.C. 2000. Women and human development: the capability approach. Cambridge: Cambridge.

NUSSBAUM, M.C. 2006. Frontiers of justice: disability, nationality, species membership. Cambridge: Havard.

OEGEMA, J. 2006. Interview. Friesch Dagblad: 19 Feb.

OSER, F. \& GMÜNDER, P. 1991. Der Mensch: Stufen seiner religiösen Entwicklung: ein strukturgenetischer Ansatz. Gütersloh: Bücherbär Im Ar.

OSER, F., SCARLETT, W.G. \& BUCHER, A., eds. 2006. Religious development in childhood and adolescence. San Francisco: Jossey-Bass.

PETERS, R.S., ed. 1967. The concept of education. London: Routledge \& Kegan Paul.

PETERS, R.S. 1975. Ethics and education. London: Routledge \& Kegan Paul.

RAHNER, K. 1939. Geist in Welt. Innsbruck: Leipzig.

RAHNER, K. 1975. Die theologische Dimension der Frage nach dem Menschen. (In Rahner, K. Schriften zur Theologie. Band 12. Zurich. S. 387-406.)

RELIGION IN GESCHICHTE UND GEGENWART. 1957-1965. Handwörterbuch für Theologie und Religionswissenschaft. 3. völlig neu bearbeitete Auflage. In Gemeinschaft mit Von Campenhausen, H. Frhr. Dinkler, E., Gloege, G., Løgstrup, K.E. Tübingen: Mohr (Paul Siebeck).

RGG

see RELIGION IN GESCHICHTE UND GEGENWART 
RIZZUTO, A.M. 1979. The birth of the living God: a psychoanalytic study. Chicago: University of Chicago Press.

SCHLEIERMACHER, F. 1799. Über die Religion: Reden an die Gebildeten unter ihren Verächtern. GmbH: De Gruyter. (Taschenbuch.)

TILLICH, P. 1963. Christianity and the encounter of the world religions. New York: Columbia.

VALENKAMP, M. \& VAN DER WALT, J.H. 2006. The spiritual dimension of "Quality of Life", with special reference to education. Paper read at the International Conference of The International Society for Quality-of-Life Studies (ISQOLS): Prospects for quality of life in the new millennium. Rhodes University, Grahamstown South Africa, Jul. 17-20, 2006.

VAN DEN BERK, T. 1999. Mystagogie: inwijding in het symbolisch bewustzijn. Zoetermeer: Meinema.

VAN DER BURG, L. 1984. Uittocht uit de illusie: over het stimuleren van en religieuze ontwikkeling bij twaalf tot zeventienjarigen in het godsdienstonderwijs. Kampen: Kok.

VAN DER KOOI, C. 2005. Godservaringen in de belevingscultuur: theologische reflecties. Kontekstueel, 20(2), Dec.

VAN VEEN, M. 2009. Een nieuwe tijd, een nieuwe kerk: de opkomst van het Calvinisme in de Lage Landen. Zoetermeer: Meinema.

VATTIMO, G. 2002. After Christianity. New York: Columbia.

VEENHOVEN, R. 1984. Conditions of happiness. London: Kluwer Academic.

VEENHOVEN, R. 2000. The four qualities of life: ordering concepts and measures of the good life. Journal of happiness studies, 1(1):1-39.

WITTGENSTEIN, L. 1998. Tractatus logico-philosophicus. Suhrkamp: Taschenbuch Wissenschaft.

ZAMBRANO, M. 1993. El hombre y lo divino. Madrid: Libros del tiempo.

ZAMBRANO, M. 2003. La rázon en la sombra: atlogica critica. Madrid: Siruela.

\section{Key concepts:}

faith

religion

religious matrix

spirituality

truth and meaning: quest for

\section{Kernbegrippe:}

geloof

godsdiens

religieuse matriks

spiritualiteit

waarheid en betekenis: soeke na 